\title{
Physiochemical and sensory properties of ice-cream sweetened with date syrup
}

\begin{abstract}
Date palm fruit is consumed as fresh fruit or processed to produce date paste and date syrup. Date syrup (DS) a natural sweetener contains mainly glucose and fructose and used with different food products. The effect of substituting sucrose with different level of DS $(0,25,50$ and $100 \%)$ on the physiochemical and sensory properties of ice cream were investigated. The overrun increased with increasing DS level while the total soluble solids and viscosity were not affected significantly. Sensory properties of DS-ice cream were similar to regular ice cream except for color, aroma and flavor. DS-ice cream developed brown color. Increasing DS level decreased the Lightness and increased yellowness values significantly. While date aroma and date flavor increased significantly with increasing DS level, milky flavor decreased significantly. Ice cream sweetened with $100 \%$ DS had the lowest $\mathrm{pH}$ and the highest values for acidity and texture. Date syrup can be used successfully to produce high quality ice cream with

unique brown color and distinctive date's aroma and flavor.
\end{abstract}

Keywords: ice cream, date syrup, sensory quality
Volume 2 Issue 3 - 2016

\author{
Isameldin B Hashim, Kamela S Al Shamsi \\ Food Science Department, College of Food and Agriculture \\ United Arab Emirates University, UAE
}

Correspondence: Isameldin B Hashim, Food Science Department, College of Food and Agriculture United Arab Emirates University, P. O. Box I555I, Al Ain, UAE, Tel +97|37|3655I, Fax+97|37|3, Email ihashim@uaeu.ac.ae

Received: March 29, 2016 | Published: May 05, 2016
Abbreviations: DS, date syrup; HFCS, high fructose corn syrup; MSNF, milk solid non fat; GS, glucose syrup; UAE, united arab emirates

\section{Introduction}

Ice cream is a frozen dessert made by mixing different ingredients including milk, cream, milk solids nonfat (MSNF), sugar, stabilizers and emulsifiers, in addition to flavors and colorants. Composition of ice cream varies depending on markets and locations (fat $8-20 \%$; MSNF 8-15\%; sugar 13-20\%; stabilizer/emulsifier $0-0.7 \%$ and total solids (TS) $36-43 \%{ }^{1}{ }^{1}$ Usually cow's milk is used to produce ice cream, but other type of milks were used including goat, ${ }^{2,3}$ buffalo,, 4 and camel. ${ }^{6}$ Fresh, frozen, canned or preserved fruits and fruit pastes pulps(strawberries, apricot, pineapple and mango) are usually used in ice cream mixes plus other fruits including fig, ${ }^{7}$ concentrated cactus pulp $^{8}$ guava $^{9}$ Blackthorn "Prunus SpinosaL. ${ }^{10 "}$ "Fruit juices and fruit fibers were also added to ice cream mixes including grape juice, ${ }^{11}$ kiwi juice ${ }^{12}$ citrus fiber ${ }^{13}$ and date fiber. ${ }^{14}$

Sucrose is the main sweetener used in ice cream production, but alternative sweeteners were used to replace sucrose including 20 and 40 dextrose equivalent corn syrup and 42 high fructose corn syrup; ${ }^{15}$ glucose syrup (GS), high fructose corn syrup (HFCS) and honey, ${ }^{16}$ dragon fruit oligosaccharide. ${ }^{17}$ Sugar alcohol ${ }^{18}$ and stevia $^{19}$ were used as alternative sweeteners to produce reduced calorie ice cream. United Arab Emiratis produce 245 thousand tons of date. ${ }^{20}$ Date fruit is consumed as fresh date or processed to different products including date syrup (DS). While DS is produced commercially by extraction and concentration under vacuum the yield could be improved by using pectinase/cellulase enzymes. ${ }^{21}$ DS contains $68-80 \%$ simple sugars (glucose and fructose) and other nutrients (proteins, lipids, pectin and minerals) and its quality varies depending on type of date variety used. ${ }^{22,23}$ High fructose DS was produced by yeast fermentation..$^{22}$ DS is used as natural sweetener. ${ }^{23}$ The main objective of this study was to investigate the effects of substituting sucrose with DS [0\% (control),
$25 \%, 50 \%$ and $100 \%$ ] on physiochemical and sensory properties of ice cream.

\section{Materials and methods \\ Materials}

Fresh whole cow milk (Al Ain Dairy), cream (Al Rawbi, Dubai), skim milk powder (Anchor ${ }^{\circledR}$ ) and date syrup (Al Foah) were purchased from a local supermarket in Al Ain, United Arab Emirates (UAE).

\section{Ice cream preparation}

The ice cream samples were prepared in duplicate in the Pilot Plant of Food Science department, College of food and Agriculture, UAE University, Al-Ain, UAE. The cream was added to the fresh whole cow milk to adjust its fat content to $5 \%$, addition of skim milk powder, mixed well and divided into four equal batches. One batch was used to make the control ice cream containing only sucrose (zero percent DS). The other batches were prepared by substituting sucrose with SD at different levels $(25,50$ and $100 \%)$. To produce ice cream with similar sweetness value, the relative sweetness of fructose and glucose were considered during calculation (fructose 1.7 and glucose 0.74 compared to sucrose 1.0 ). The mixtures were then pasteurized at $72^{\circ} \mathrm{C}$ in hot oven for $30 \mathrm{~min}$, cooled, aged (stored at $4^{\circ} \mathrm{C}$ for 20hours) and whipped in the ice cream maker (CarpigianiLabo, Italy) for 15$20 \mathrm{~min}$. The ice cream was collected to measure the volume then filled in small cups and stored at $-18 \mathrm{C}$ till analyzed.

\section{Physicochemical properties of DS ice cream}

Overrun, the increase in ice cream volume over the volume of the ice cream mix due to incorporation of air was measured using this equation [(ice cream volume- ice cream mix volume)/ice cream mix volume $] \times 100 .^{11,24}$

pH, acidity and TSS: Ice cream $\mathrm{pH}$ was measured using a pH meter 
(Thermo orion, Thermo electron corporate, USA). The acidity was measured by titration against $0.1 \mathrm{~N} \mathrm{NaOH}$ and results were expressed as $\%$ lactic acid. Total soluble solid (TSS) of ice cream were measured by a refractometer (N-50 E ATAGO refractometer, Japan).

Viscosity was measured for melted ice cream (stored at $4^{\circ} \mathrm{C}$ ) by viscometer (Hybrid Rheometer 2, TA instruments, USA).

Texture Analysis: Ice cream samples were held at $-18^{\circ} \mathrm{C}$ for 24 hours. Texture analyzer (Brook field texture analyzer, USA) was used to determine the hardness. Three measurements/sample were done using a $5 \mathrm{~mm}$ stainless steel cylindrical probe attached to a $25 \mathrm{~kg}$ load cell. The penetration depth at the center of the samples was $10 \mathrm{~mm}$ at $2.0 \mathrm{~mm} / \mathrm{s}$ penetration. Hardness $(\mathrm{N})$ was determined as the peak compression force during penetration.

Color: Ice cream color was measured by Hunter lab colorimeter (color flex hunter lab, USA). The colorimeter was calibrated with a white and black reference plate before measuring the L "lightness", a "redness" and b "yellowness".

Sensory Evaluation: Eleven trained panelists who enrolled on the sensory evaluation course at Food Science Department, College of Food and Agriculture, UAE University were selected to evaluate ice cream samples in duplicate using Quantitative Descriptive Analysis. During the orientation sessions, panelists agreed on the sensory

Table I Physicochemical properties of date syrup ice cream $(n=2)$ attributes, evaluated the reference ice cream samples and agreed on its intensities. Sensory properties of ice cream (appearance, appearance texture, color, milky aroma, date aroma, coldness, sweetness, milky flavor, date flavor, firmness, smoothness, mouth coating and overall quality) were evaluated using $15-\mathrm{cm}$ scale. The ice cream samples were presented to panelists in small plastic cups coded with 3-digit random numbers in individual booths under normal daylight. Panelists were instructed to drink water between samples to clear their palates.

Statistical Analysis: The date were analyzed using one way analyze the Variance (ANOVA) using (SPSS 18.0 for Windows, SPSS Inc., Chicago, IL, USA). Duncan's Multiple Range Test $(\mathrm{P} \leq 0.05)$ was to compare ice cream means.

\section{Results and discussion}

The physical and chemical properties of ice cream samples are shown in Table 1. The overrun value of control ice cream is 19.0 which was low compared to the reported results, this may be due to the absence of stabilizers and emulsifiers. The overrun values of DS ice cream samples ranged from 20.2to 23.5. The higher overrun raises the creaminess of the ice cream. ${ }^{25}$ While the overrun values increased with increasing DS there were no significantly different among different levels of DS and control ice cream. It was reported that honey, HFCS, CS, sucralose and maltitol decreased overrun..$^{16,18}$

\begin{tabular}{|c|c|c|c|c|c|c|}
\hline Sample & Overrun \% & $\mathrm{pH}$ & TSS $\%$ & Viscosity (M pa.s) & $\begin{array}{l}\text { Acidity (lactic } \\
\text { acid) }\end{array}$ & Hardness (g) \\
\hline Control & $19.0 \pm 1.03^{\mathrm{a}^{2}}$ & $5.7 I \pm 0.0 I^{b}$ & $26.5 \pm 0.7^{\mathrm{a}}$ & $0.24 \pm 0.00^{\mathrm{a}}$ & $0.26 \pm 0.02^{\mathrm{a}}$ & $797.0 \pm 47.4^{\mathrm{b}}$ \\
\hline $25 \%$ DSI & $20.2 \pm 1.5^{\mathrm{a}}$ & $5.67 \pm 0.04^{b}$ & $26.5 \pm 0.7^{\mathrm{a}}$ & $0.22 \pm 0.02^{\mathrm{a}}$ & $0.33 \pm 0.0 \mathrm{I}^{\mathrm{b}}$ & $843.0 \pm 63.0^{\mathrm{b}}$ \\
\hline $50 \% \mathrm{DS}$ & $22.4 \pm 1.0^{\mathrm{a}}$ & $5.67 \pm 0.0 \mathrm{I}^{\mathrm{b}}$ & $27.0 \pm 0.0^{\mathrm{a}}$ & $0.22 \pm 0.02^{\mathrm{a}}$ & $0.34 \pm 0.0 \mathrm{I}^{\mathrm{b}}$ & $369.0 \pm 38.6^{\mathrm{a}}$ \\
\hline $100 \%$ DS & $23.5 \pm 1.0^{\mathrm{a}}$ & $5.56 \pm 0.04^{\mathrm{a}}$ & $27.5 \pm 0.7^{\mathrm{a}}$ & $0.24 \pm 0.00^{\mathrm{a}}$ & $0.47 \pm 0.04^{c}$ & $262.0 \pm 40.3 \mathrm{I}^{\mathrm{a}}$ \\
\hline
\end{tabular}

\section{'DS, date syrup}

${ }^{2}$ Means values with different letters on the same column significantly different $(p \leq 0.05)$.

The $\mathrm{pH}$ of DS varies based on date variety, extraction method and concentration. The $\mathrm{pH}$ of control ice cream is 5.71 which is slightly lower compared to the reported results. Increasing DS level decreased ice cream $\mathrm{pH}$. Ice cream sweetened with DS (100\%) had significantly lower $\mathrm{pH}$ compared to control and $25 \& 50 \%$ DS. However acidity increased with increasing DS level. Similar results reported for ice cream sweetened with honey or sucrose and honey $(1: 1) .{ }^{16}$

DS had no effect on TSS of ice cream Control and DS ice creams had similar TSS.

Control ice cream and DS ice cream had similar viscosity. Using DS as alternative sweetener had no effect on ice cream viscosity.
Similar effect reported for HFCS ice cream, while honey and glucose syrup ice cream had significantly higher viscosity compared to regular (sucrose) ice cream. ${ }^{16}$

Control ice cream and 25\% DS ice cream had similar hardness values and similar results was reported when sucrose subsisted by Xylitol. ${ }^{18}$ Increasing DS levels to 50 and $100 \%$ produced significantly softer texture ice cream while maltitol and sucralose produced harder ice cream. ${ }^{18}$

The color ( $\mathrm{L}$, a and $\mathrm{b}$ values) of ice cream samples are presented in Figure 1. DS had significant effects on ice cream color. DS ice cream develop a browner color. Lightness values (L) decreased with 
increasing DS level and similar results were reported for honey, corn syrup and HFCS ice creams. ${ }^{16}$ While redness (a) and yellowness (b) increased with increasing DS level. This indicated that Ds could be used as natural coloring agent to produce colored ice cream (golden to brown) depending on date variety, extraction method and concentration level. Similar results were reported for ice cream sweetened with Erythritol, maltitol, sucralose and xylitol. ${ }^{18}$
Sensory quality of ice cream is shown in Table 2. Most sensory properties were not significantly affected by DS. Control and DS ice cream had similar sensory quality (appearance, milky aroma, firmness, smoothness, mouth coating and sweetness). Ice cream color, date aroma and date flavor intensities were significantly increased with increasing DS level while significantly decreasing milky flavor (Figure 2). DS ice cream developed brown color and date aroma and date flavor.

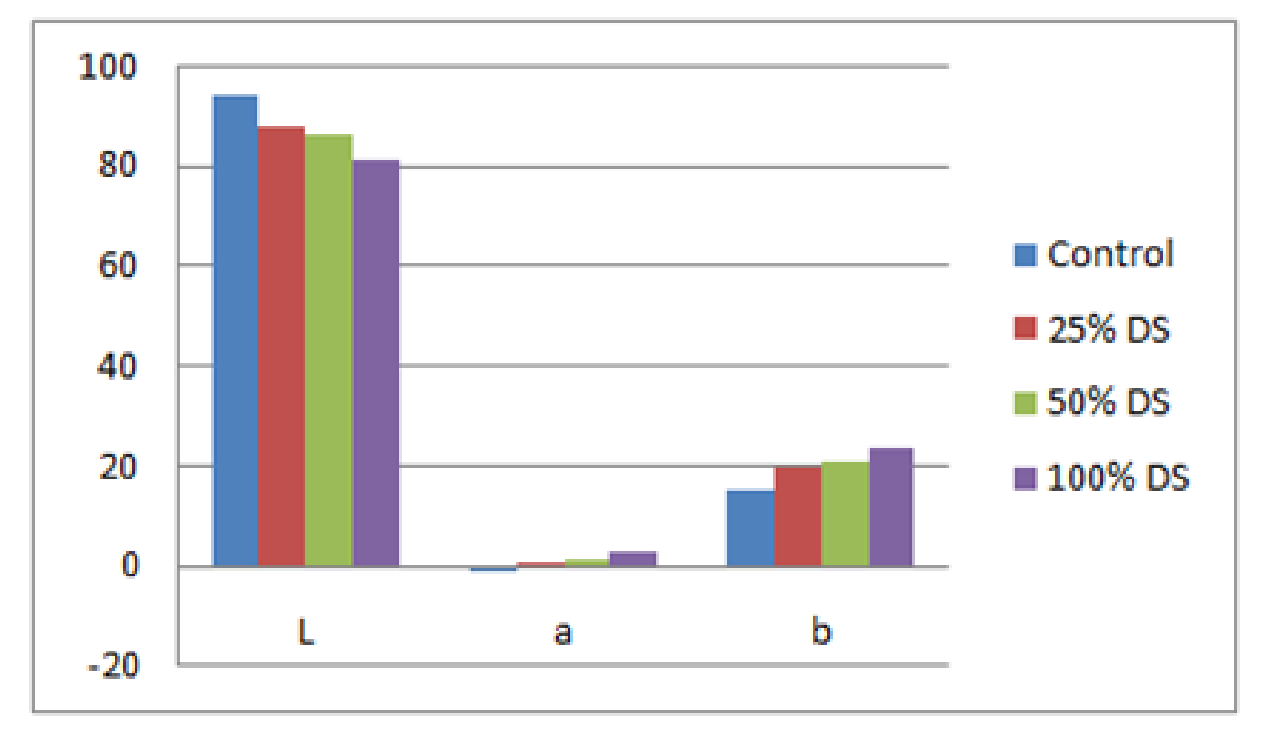

\section{L, lightness; a, Redness; b, Yellowness}

Figure I Color of date syrup ice cream $(n=3)$.

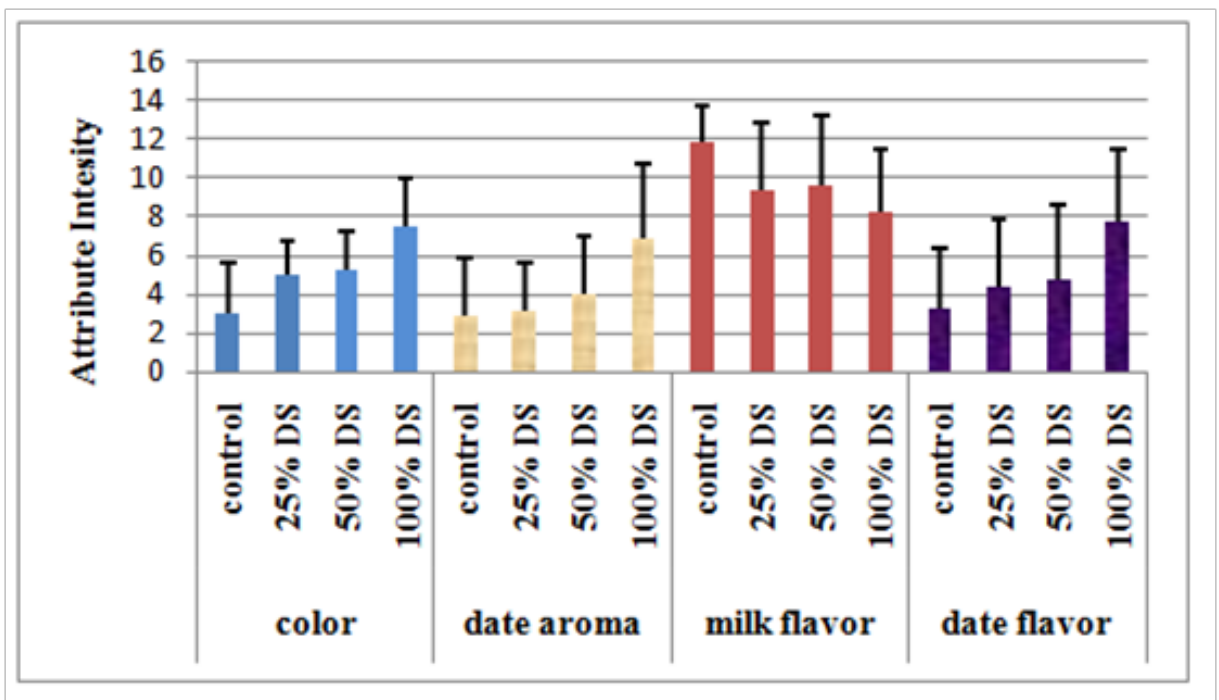

DS, date syrup

Figure 2 Sensory properties of date syrup ice cream $(n=22)$. 
Table 2 Sensory properties of date syrup ice cream $(n=22)$

\begin{tabular}{|c|c|c|c|c|c|c|c|}
\hline Ice cream & Appearance & Milky aroma & Smoothness & Sweetness & Firmness & Mouth coating & $\begin{array}{l}\text { Overall } \\
\text { quality }\end{array}$ \\
\hline Control & $11.8 \pm 1.6^{\mathrm{a} 2}$ & $10.5 \pm 1.2^{\mathrm{a}}$ & $11.6 \pm 2.5^{a}$ & $10.8 \pm 2.3^{a}$ & $8.3 \pm 1.9^{a}$ & $11.1 \pm 1.8^{a}$ & $10.6 \pm 1.4^{\mathrm{a}}$ \\
\hline $25 \% \mathrm{DS}^{\prime}$ & $11.6 \pm 1.5^{\mathrm{a}}$ & $9.4 \pm 1.4^{\mathrm{a}}$ & $11.3 \pm 1.9^{a}$ & $10.3 \pm 2 . I^{a}$ & $7.8 \pm 1.2^{\mathrm{a}}$ & $10.9 \pm 1.6^{a}$ & $10.7 \pm 1.0^{\mathrm{a}}$ \\
\hline $50 \%$ DS & $11.3 \pm 1.8^{\mathrm{a}}$ & $9.2 \pm 1.7^{\mathrm{a}}$ & $11.3 \pm 1.9^{a}$ & $9.9 \pm 1.9^{a}$ & $7.0 \pm 1.5^{\mathrm{a}}$ & $10.8 \pm 1.6^{a}$ & $10.6 \pm 1 . I^{a}$ \\
\hline $100 \%$ DS & $11.1 \pm 1.4^{\mathrm{a}}$ & $8.9 \pm 1.5^{a}$ & $12.3 \pm 2.4^{\mathrm{a}}$ & $9.7 \pm 2.1^{\mathrm{a}}$ & $6.4 \pm 2.4^{\mathrm{a}}$ & $10.6 \pm 1.9^{a}$ & $10.2 \pm 1.6^{\mathrm{a}}$ \\
\hline
\end{tabular}

'DS, date syrup

${ }^{2}$ Means values with different letters on the same column significantly different $(p \leq 0.05)$.

\section{Conclusion}

Date syrup could be used as natural sweetener, colorant and flavoring agent to produce ice cream with unique color and aroma/ flavor.

\section{Acknowledgements}

The authors are extremely grateful to Mr. Ismail Abdul Haliem, Mr. Baboucarr Jobe and Dr. Priti Devi for technical assistance and the panelists for participating on the sensory evaluation.

\section{Conflict of interest}

The author declares no conflict of interest.

\section{References}

1. Arbuckle WS. Ice cream. 4th ed. USA: Springer Science \& Business Media; 2013.

2. Pandya AJ, Ghodke KM. Goat and sheep milk products other than cheeses and yoghurt. Small Ruminant Research. 2007;68(1-2):193-206.

3. McGhee CE, Jones JO, Park YW. Evaluation of textural and sensory characteristics of three types of low-fat goat milk ice cream. Small Ruminant Research. 2015;123(2-3):293-300.

4. Minhas KS, Sidhu JS, Mudahar G, et al. Effect of different concentrations of stabilizers and ageing times on the viscosity of plain ice cream mix made from buffalo Milk. Journal of Food Science and Technology. 2000;37(6):602-608.

5. Minhas KS, Sidhu JS, Mudahar GS, et al. Flow behavior characteristics of ice cream mix made with buffalo milk and various stabilizers. Plant Foods Hum Nutr. 2002;57(1):25-40.

6. Ahmed ASM, El Zubeir IEM. Processing properties and chemical composition of low fat ice cream made from camel milk using natural additives. International J Dairy Sci. 2015;10(6):297-305.

7. Murtaza MA, Huma N, Mueen-Ud-Din G Shabbir MA, et al. Effect of fat replacement by Fig addition on ice cream quality. Int J Agri Biol. 2004;6(1):68-70.

8. El-Samahy SK, Youssef KM, Moussa-Ayoub TE. Producing ice cream with concentrated cactus pear pulp: A preliminary study. J of Professional Association for Cactus Development PACD. 2009;11:1-12.

9. Patel HH, Amin BK. Formulation and Standardization of different milk Ice-cream fortified with pink guava pulp. International $J$ of Dairy Sci. 2015;10(5):219-222.
10. Kavaz Yuksel A. The Effects of Blackthorn (Prunus Spinosa L.) addition on certain quality characteristics of Ice Cream. J of Food Quality. 2015;38(6):413-421.

11. Soukoulis C, Tzia C. Response surface mapping of the sensory characteristics and acceptability of chocolate ice cream containing alternate sweetening agents. Journal of Sensory Studies. 2010;25(1):5075 .

12. Sun-Waterhouse D, Edmonds L, Wadhwa SS, et al. Producing ice cream using a substantial amount of juice from kiwifruit with green, gold or red flesh. Food Research International. 2013;50(2):647-656.

13. Dervisoglu M, Yazici F. Note. The effect of citrus fiber on the physical, chemical and sensory properties of ice cream. Food Science and Technology International. 2006;12(2):159-164.

14. Yangilar F. Mineral contents and physical, chemical, sensory properties of ice cream enriched with date fibre. Italian $J$ of Food Science. 2015;27(3):397-406.

15. Hagiwara T, Hartel RW. Effect of sweetener, stabilizer, and storage temperature on ice recrystallization in ice cream. $J$ Dairy Sci. 1996;79(5):735-744.

16. Ozdemir C, Dagdemir E, Ozdemir S, et al. The effects of using alternative sweeteners to sucrose on ice cream quality. J Food Quality. 2008;31(4):415-428.

17. Wichamanee Y, Acharaphan M, Santad W. Effect of dragon fruit oligosaccharide, stabilizer and sucrose on physical and sensory quality of ice cream. International Food Research Journal. 2016;23(1):269-276.

18. Khuenpet K, Jittanit W, Watchrakorn T, et al. Effect of the sweeteners on the qualities of vanilla-flavored and yoghurt-flavored ice cream. Kasetsart J Natural Science. 2015;49(1):133-145.

19. Ozdemir C, Arslaner A, Ozdemir S, et al. The production of ice cream using stevia as a sweetener. J Food Sci \& Technol. 2015;52(11):75457548 .

20. FAOSTAT; 2015

21. Al-Hooti SN, Sidhu JS, Al-Saqer JM, et al. Chemical composition and quality of date syrup as affected by pectinase/cellulase enzyme treatment. Food Chemistry. 2002;79(2):215-220.

22. Putra MD, Abasaeed AE, Ali EM, et al. Utilization of pitted dates for the production of highly concentrated fructose syrups by s. cerevisiae. Chemical Engineering Transactions. 2014;38:397-402.

23. Mostafazadeha AKM, Sarshara M, Javadiana SH, et al. Separation of fructose and glucose from date syrup using resin chromatographic method: Experimental data and mathematical modeling. $J$ of Separation and Purification Technology. 2011;79(1):72-78. 
24. Jimenez-Florez R, Klipfel NJ, Tobias J. Ice cream and frozen desserts. In YH Hui editor. Dairy Science and Technology Handbook 2. New York, USA: Product Manufacturing VCH Publishers; 1993. p. 57-159.
25. Kilara A, RC Chandan. Ice cream and frozen desserts. In: YH Hui editor. Handbook of Food Products Manufacturing. Hoboken, New Jersey, USA: Wiley \& Sons, Inc; 2006. p. 593-633. 